\title{
REFORMAR LAS COSTUMBRES. PABLO DE OLAVIDE Y SU MODELO DE OCIO PARA LAS NUEVAS POBLACIONES DE SIERRA MORENA Y ANDALUCÍA (1767-1776)
}

\section{Reform the Customs. Pablo de Olavide and his Model of Leisure for the New Settlements of Sierra Morena and Andalusia (1767-1776)}

\author{
Francisco José PÉREZ FERNÁNDEZ \\ Universidad de Jaén \\ fjperezfdez@telefonica.net \\ Adolfo HAMER FLORES \\ Universidad Loyola Andalucía \\ ahamer@uloyola.es
}

Fecha de recepción: 22/07/2019

Fecha de aceptación definitiva: 23/12/2019

RESUMEN: La controvertida trayectoria biográfica de Pablo de Olavide es bien conocida gracias a varios trabajos de investigación que han analizado gran parte de su vida y sus acciones. Su afán reformista, influenciado por las ideas y corrientes de la Ilustración, acabó en una sentencia inquisitorial condenatoria, pero, afortunadamente, este proceso nos permite conocer su particular modo de entender la religión y las actividades de ocio. Estas últimas han sido analizadas en conjunto y, sobre todo, centrándose en lo ocurrido en la ciudad de Sevilla, habiendo dejado en segundo plano lo que sucedió en esas nuevas colonias que se crearon bajo sus órdenes en Sierra Morena y Andalucía a partir de 1767. De ahí que el objetivo de este trabajo sea el de realizar una aproximación al modelo de ocio que Olavide trató 
de implantar en esas poblaciones, así como al rechazo o resistencia que este generó en el clero y las clases populares.

Palabras clave: Ilustración; Pablo de Olavide; reforma del ocio; siglo XVIII.

ABSTRACT: The controversial biographical trajectory of Pablo de Olavide is well known thanks to several research works that have analyzed much of his life and his actions. His reformist zeal, influenced by the ideas and currents of the Enlightenment, ended in a condemnation of the Inquisition, but, fortunately, this process allows us to know his particular way of understanding religion and leisure activities. These have been analyzed as a whole and, above all, focusing on what happened in the city of Seville, having left in the background what happened in those new colonies that were created under his orders in Sierra Morena and Andalusia from 1767 onwards. Hence, the objective of this work is to make an approximation to the leisure model that Olavide tried to implant in those populations, as well as the rejection or resistance that this generated in the clergy and the popular classes.

Key words: Enlightenment; Pablo de Olavide; leisure time reform; eighteenth century.

\section{INTRODUCCIÓN}

El limeño Pablo de Olavide brilla con luz propia entre los ilustrados que se movieron por las instituciones de gobierno de la España de Carlos III $^{1}$. Su talento y capacidades le permitieron finalizar sus estudios universitarios cuando apenas había superado la adolescencia, pasando muy pronto a desempeñar importantes cargos académicos y a ocupar una plaza de oidor en la Audiencia y Cancillería Real de Lima. Aún más, se le encomendaron las labores de reconstrucción de su ciudad natal, tras el terremoto de 1746, cuando apenas contaba con veintiún años. Ya entonces daba buenas muestras de la influencia que las ideas ilustradas tenían en sus palabras y acciones, con lo que también se iniciaron los problemas y conflictos con los que tuvo que lidiar durante casi toda su vida. En cualquier caso, serían sus viajes por varios países europeos ${ }^{2}$ los que terminaron por definir por

1. Los trabajos que se han ocupado de su trayectoria biográfica y principales realizaciones son muy abundantes, aunque siguen siendo imprescindibles sus dos mejores biografías: DeFOURNEAUX, Marcelin. Pablo de Olavide, el afrancesado. México: Editorial Renacimiento, 1965, y PERDICES DE BLAS, Luis. Pablo de Olavide (1725-1803), el ilustrado. Madrid: Editorial Complutense, 1992. En lo que respecta a su proceso inquisitorial y conflictos de poder en la corte, algunos de los trabajos más recientes del profesor Gómez Urdáñez resultan esenciales: Gómez UrdáÑEz, José Luis. «Con la venia de Carlos III. El castigo ejemplar de Olavide, consecuencia de la venganza de Grimaldi contra el conde de Aranda». Vegueta. Anuario de la Facultad de Geografía e Historia, 2015, 15, pp. 373-400.

2. Su matrimonio en 1755 con Isabel de los Ríos, una viuda rica, facilitó que hiciera tres viajes, sumando treinta y seis meses en un intervalo de ocho años (1756-1764), por distintos territorios 
completo su particular modo de entender los defectos del mundo que le rodeaba y su, imprudente en demasiadas ocasiones, forma de transformar ese entorno siempre que sus empleos de gobierno se lo permitieron.

No puede extrañar mucho, por tanto, que los sectores más reaccionarios, tanto de la Administración como de la Iglesia, considerasen un verdadero desafío sus iniciativas e ideas; especialmente porque parecían sintonizar con las de otros ilustrados de la Corte, como Pedro Rodríguez de Campomanes, el conde de Aranda o Miguel de Múzquiz. Unos contactos que le facilitaron la posibilidad de ser el encargado de la puesta en marcha y gobierno de las nuevas poblaciones que se establecieron a partir de 1767 , fundamentalmente con colonos centroeuropeos traídos a España tras la firma de una contrata con un militar de origen bávaro, en distintos espacios despoblados de la Sierra Morena giennense, en las proximidades del camino real entre Córdoba y Carmona y en la provincia de La Mancha. Como superintendente de estas Nuevas Poblaciones de Sierra Morena y Andalucía disfrutó de una serie de competencias y prerrogativas que le permitieron hacer realidad su deseo de erradicar diferentes costumbres que consideraba atrasadas y perjudiciales ${ }^{3}$, las cuales se vieron incluso más reforzadas por los otros dos cargos que también se le confirieron con vistas a evitar conflictos que impidiesen el éxito de esas nuevas colonias: la Asistencia de Sevilla y la Intendencia de Ejército de los cuatro reinos de Andalucía ${ }^{4}$.

No obstante, la prudencia nunca fue uno de los rasgos más destacados de la personalidad de Olavide. Su impulsividad lo llevó con frecuencia a mantener disputas y generaba con facilidad en quienes lo oían opiniones como la del ingeniero militar Carlos Lemaur, encargado de las obras del paso de Despeñaperros, quien nos dice que era «un hombre que habla[ba] de todas cosas sin mucha reflexión, y con poco conocimiento, ya las materias sean filosóficas ya sean de religión, pues las más de las veces caía en contradicción consigo mismo» ${ }^{5}$. Una actitud que acabó

europeos, entre los que destacaron Francia y los situados en la península itálica. En ese tiempo la visita a Roma le causó un fuerte impacto, a la par que el tomar contacto con destacados ilustrados franceses -incluido Voltaire, en cuya finca Les Délices estuvo alojado- le hizo rechazar más aún si cabe cuestiones que consideraba supersticiones o simples medios para lograr el dinero de los fieles.

3. Este trabajo se inserta, por tanto, en una corriente historiográfica que viene profundizando en distintos aspectos vinculados con el ocio y la vida cotidiana durante la Edad Moderna desde hace algunas décadas. Entre la extensa producción bibliográfica existente resulta imprescindible la consulta de ARIAS de SAavedra Alías, Inmaculada (coord.). Vida cotidiana en la España de la Ilustración. Granada: Universidad de Granada, 2012; NúÑEz Roldán, Francisco (coord.). Ocio y vida cotidiana en el mundo hispánico en la Edad Moderna. Sevilla: Universidad de Sevilla, 2007; y TORRIONE, Margarita (dir.). España festejante: el siglo XVIII. Málaga: Diputación de Málaga, 2000.

4. Gazeta de Madrid, n. ${ }^{\circ} 25$, martes 23 de junio de 1767, p. 201. El 23 de junio de 1767 , el rey "ha nombrado a D. Pablo de Olavide para que le suceda [a Ramón de Larumbe] en la Intendencia y Asistencia [de Sevilla] en atención a su celo y constante aplicación por el servicio del rey y bien del público, confiriéndole también la Superintendencia de las Nuevas Poblaciones proyectadas en Sierra Morena".

5. Archivo Histórico Nacional -en adelante AHN-, Inquisición, leg. 1866, pieza 3, testigo 139 (Carlos Lemaur, 1777). 
proporcionando al Tribunal del Santo Oficio testimonios suficientes como para dictar una sentencia condenatoria en la que fue calificado, entre otros, como hereje formal y miembro podrido de la religión. Esos testimonios, dado que muchos de los declarantes estaban directa o indirectamente vinculados con las Nuevas Poblaciones, ofrecen informaciones muy interesantes acerca de las medidas relacionadas con el ocio y empleo del tiempo de descanso que el superintendente trató de implantar en un sociedad caracterizada por la presencia generalizada de labradores con explotaciones familiares y que vivían en un entorno donde muchos elementos que se consideraban perjudiciales, como las órdenes regulares, la compraventa y herencia de cargos públicos o la amortización de la propiedad, estaban prohibidos.

Algunas de estas informaciones han sido empleadas en estudios generales como los de Marcelin Defourneaux y Luis Perdices de Blas, en los que existe la tendencia a centrar el discurso en lo que ocurrió en la ciudad de Sevilla, pero nunca han sido estudiadas como evidencias de la plasmación de un pensamiento diferente en un lugar concreto aprovechando que los beneficiarios de los cambios serían labradores y artesanos y no la población que residía en una de las mayores ciudades del sur peninsular. Es por ello por lo que el objetivo principal de esta investigación consistirá en realizar una aproximación al modelo de ocio que Pablo de Olavide trató de establecer entre los colonos de las Nuevas Poblaciones de Sierra Morena y Andalucía valiéndose de las amplias competencias que le confería su cargo de superintendente ${ }^{6}$. Emplearemos para este fin, sobre todo, las ya mencionadas declaraciones del más de centenar y medio de testigos que la Inquisición recopiló durante la instrucción de su proceso inquisitorial7 ${ }^{7}$. En ellas se plasmaron algunos datos relacionados con el tema que aquí nos ocupa, fundamentalmente sirviendo de contexto cuando exponen otras cuestiones, circunstancia que explica su elevada dispersión y que, por lo general, ofrezcan pocos detalles. En cambio, el hecho de no constituir el objetivo principal de la respuesta que se les pedía garantiza un mayor grado de objetividad en lo narrado. En cualquier caso, no hemos renunciado a integrar también en nuestra investigación todos aquellos testimonios documentales y referencias bibliográficas que permiten completar, ampliar y entender lo que aportan dichos testimonios.

6. Estas atribuciones, derivadas de una férrea defensa del regalismo entre los ministros ilustrados de Carlos III, alimentaron en parte del clero de las nuevas colonias un fuerte rechazo hacia las iniciativas y decisiones de Pablo de Olavide. Del mismo modo, tampoco fue fácil a nivel estatal esa dialéctica entre Estado e Iglesia: véase CARO LóPEz, Ceferino. "Censura gubernativa, Iglesia e Inquisición en el siglo XVIII. Hispania Sacra, 2004, 56, pp. 479-511.

7. La mayor parte de la documentación recopilada durante la instrucción de su causa se encuentra actualmente incluida en un voluminoso legajo de la sección Consejo de Inquisición del Archivo Histórico Nacional de España. Dado que este se distribuye en diez piezas de considerable grosor y que contiene declaraciones y documentos fechados entre 1766 y 1781, hemos optado en el presente trabajo por ofrecer al lector referencias concretas que faciliten la localización del testimonio citado. 
Las decisiones adoptadas por Olavide en sus años al frente de las nuevas colonias, como ya hemos expuesto, no tardaron en generar fricciones con las autoridades eclesiásticas e incluso con los propios colonos, que no compartieron de manera generalizada ni las formas ni el fondo de lo que se les ofrecía; de ahí que también consideremos de interés estudiar esas resistencias que mostraron al ejercicio del poder. El cambio desde arriba que el limeño empleó para esas reformas, incluida la del ocio que aquí estudiaremos, constituyó uno de los principales inconvenientes para el éxito y viabilidad de aquello que consideraba beneficioso para una sociedad mejor. Sus deseos se frustraron en 1776, pero nos queda esta interesante, a la par que breve, medida reformista que estuvo en vigor durante varios años en una provincia de nuestro país.

\section{Labora ET NON ORA. Pablo de Olavide y Su CONCEPTO De los días Festivos FRENTE A LOS DÍAS DE TRABAJO}

Es probable que una de las mejores muestras del pensamiento de Olavide en relación con el modo en el que concebía la vida de los colonos de las Nuevas Poblaciones sea la que manifestó al catalán Antonio Capmany ${ }^{8}$, en 1775, al defender "que lo que importaba era hacer hijos, trabajar y dejarse de sermones y culto divino"?. Toda una declaración de intenciones que explica muy bien que su idea del tiempo de descanso y sociabilidad de los colonos no iba a ajustarse a las actividades de culto y a las costumbres establecidas en torno a esas actividades. El destacado papel que concedía al trabajo, del que se derivaba su firme rechazo a la ociosidad y vagancia, le hizo manifestar abiertamente su malestar por el hecho de que en días no festivos los colonos acudiesen a misa o rezasen en las iglesias ${ }^{10}$.

Su gran detractor en las colonias, el capuchino alemán fray Romualdo de Friburgo, responsable en buena medida de que el proceso inquisitorial que finalmente lo condenó no se quedase estancado en la fase de averiguaciones, llegó a compendiar las actividades con las que consideraba que el limeño había profanado los días festivos en las nuevas colonias: obligaba a trabajar, autorizaba la celebración de mercados semanales que no se interrumpían en las horas de culto, ejecutaba las sentencias judiciales, promovía bailes públicos y se divertía con

8. Antonio Capmany Surís y de Montpaláu (Barcelona, 1742 - Cádiz, 1813), destacado militar y filósofo, colaboró en las Nuevas Poblaciones de Sierra Morena, a petición de Pablo de Olavide, para aportar a estas colonias algunas familias catalanas entre 1774 y 1775 (CORONAS VIDA, Luis Javier. "Colonos catalanes en las Nuevas Poblaciones de Sierra Morena». En Actes Primer Congrés d'Història Moderna de Catalunya. Barcelona: Universitat de Barcelona, 1984, I, pp. 42-43). Sobre el perfil de Capmany es fundamental la consulta de FERnÁndez de la Cigoña, Francisco José y CANTERO NúñEz, Estanislao. Antonio de Capmany (1742-1813). Pensamiento, obra histórica, política y jurídica. Madrid: Fundación Francisco Elías de Tejada y Erasmo Percopo, 1993.

9. AHN, Inquisición, leg. 1866, pieza 3, testigo 138 (Antonio Capmany, 1777).

10. AHN, Inquisición, leg. 1866, pieza 2, testigo 56 (Pedro de Vera, 1775). 
"máscaras y comedias»" Veamos qué hubo de cierto en estas afirmaciones, para lo cual trataremos las tres primeras a continuación, dejando los bailes y las máscaras y comedias para el siguiente apartado, donde analizaremos monográficamente dichas manifestaciones lúdicas.

La urgente necesidad de desmontar las tierras para sembrarlas y de construir viviendas para los colonos, así como los edificios imprescindibles en los núcleos urbanos principales, constituyó el principal argumento esgrimido por Pablo de Olavide durante los primeros años para considerar como laborables todas las festividades a excepción de las más solemnes como la Navidad y el Corpus Christi ${ }^{12}$. Una decisión que, aunque contó con el visto bueno del Gobierno, no se plasmó en una petición previa de licencia al capellán mayor y los párrocos. Situación que se mantuvo hasta un momento que no podemos precisar situado entre 1772 y 1773, cuando las reiteradas quejas de Juan Lanes y Duval, capellán mayor y vicario general de Sierra Morena, hicieron que el superintendente comenzase a pedirle dichas licencias; de este modo, la situación volvió a la normalidad hasta que el subdelegado Miguel de Ondeano, ante la ausencia de Olavide a partir de 1776, se hizo cargo del gobierno de esas colonias y ordenó de nuevo que se trabajase en días festivos sin pedirla ${ }^{13}$. Un proceder que no debió de tener mucho recorrido pues no contamos con ninguna queja en este sentido en los años siguientes.

En cualquier caso, esos días festivos en los que se ordenaba que había que trabajar se redujeron considerablemente después de los primeros años, estando vinculados solo ya a los momentos de mayor urgencia por las cosechas o por las siembras $^{14}$, como ocurría en otros lugares del país. Nada que ver con aquellos primeros tiempos en los que, al parecer, no cabía opción a desobedecer el mandato de acudir a trabajar. El capellán suizo Francisco Antonio Henseler, que estuvo en las colonias durante algunos meses en 1769, afirmó que los colonos le contaban que esos días de fiesta, incluso aunque estuvieran oyendo misa, los soldados, pertrechados con bayoneta calada, siguiendo órdenes de los comandantes civiles los sacaban de las iglesias para que fueran al trabajo ${ }^{15}$. Leonardo Felder, colono establecido en el Departamento $3 .^{\circ}$ de La Carolina, sostuvo que un día de fiesta que acudió, junto a otros alemanes, para oír misa se encontró con el superintendente, el cual les ordenó que abandonasen el lugar y que, de no hacerlo inmediatamente, los pondría presos ${ }^{16}$. No obstante, estos impulsos fueron puntuales, permitiendo

11. AHN, Inquisición, leg. 1866, pieza 2, testigo 46 (fray Romualdo de Friburgo, 1775).

12. AHN, Inquisición, leg. 1866, pieza 3, testigo 102 (Juan Calvet, 1777).

13. AHN, Inquisición, leg. 1866, pieza 2, testigo 67 (Francisco de la Coba, 1776); pieza 3, testigo 141 (Juan Lanes y Duval, 1777).

14. AHN, Inquisición, leg. 1866, pieza 2, testigo 56 (Pedro de Vera, 1775).

15. AHN, Inquisición, leg. 1866, pieza 3, testigo 82 (Francisco Antonio Henseler, 1776).

16. AHN, Inquisición, leg. 1866, pieza 3, testigo 99 (Leonardo Felder, 1777). 
habitualmente que oyeran misa los que acudían para ello y mandándolos a trabajar en cuanto esta concluía ${ }^{17}$.

La importancia de facilitar el acceso a artículos básicos, tanto a los colonos como a otros residentes en las poblaciones, fue un elemento tenido en cuenta desde antes incluso de iniciarse la colonización. El artículo 47 del fuero de población de 5 de julio de 1767 dejaba al criterio del superintendente el establecer donde considerase adecuado un mercado franco semanal ${ }^{18}$, aunque sin fijar $\mathrm{o}$ limitar cuándo tendría lugar. Como era de esperar, Olavide pensó inmediatamente en los días de fiesta, con lo cual no se interrumpirían las jornadas de trabajo en la agricultura y la artesanía. Las dos capitales de esta nueva jurisdicción, La Carolina y La Carlota ${ }^{19}$, albergaron cada semana esos mercados libres que permitieron no solo intercambiar productos entre los colonos. sino, sobre todo, adquirir géneros foráneos sin el sobrecoste de impuestos. Su realización en las jornadas festivas no podía ser del agrado del clero, preocupado por que esos días se dedicasen preferentemente a las actividades de culto; pero el problema principal derivó de que las transacciones realizadas en los mercados de la capital de las colonias de Sierra Morena no se interrumpían ni en las festividades más solemnes ${ }^{20}$ ni mientras duraban los oficios religiosos en las restantes ${ }^{21}$. De ahí que, tras la marcha de Olavide, se pusiese sobre la mesa la posibilidad de trasladar su realización a otro día de la semana. El capellán mayor hizo de intermediario en la petición que elevaron algunos labradores de las colonias al obispo de Jaén, cuya mediación se esperaba que inclinara la balanza hacia el cambio $^{22}$. Desconocemos si esta iniciativa tuvo algún grado de éxito, pero, en caso de tenerlo, solo pudo afectar a las Nuevas Poblaciones de Sierra Morena, ya que en la capital de las colonias de Andalucía sabemos que en una fecha tan tardía como 1792 se seguía celebrando con normalidad un mercado libre o franco todos los días de fiesta ${ }^{23}$.

17. AHN, Inquisición, leg. 1866, pieza 3, testigo 100 (Juan Adam Spies, 1777).

18. "Establecerá el superintendente, en el paraje que juzgue más conveniente, un mercado franco semanal, dos o más según la extensión de los nuevos pueblos, porque de esta manera estarán surtidos los pobladores y la tropa de cuanto necesiten a cómodos y corrientes precios». Véase HAMER Flores, Adolfo (ed.). Legislación Histórica Neopoblacional. Disposiciones normativas emanadas del poder central en las Nuevas Poblaciones de Sierra Morena y Andalucía (1767-1835). Madrid: Bubok Publishing, 2018, p. 69.

19. El viajero francés Jean François Peyron, que pasó por La Carlota en 1778, nos dice que allí estaba el mercado público donde sus vecinos iban a vender sus granos y frutos (HAMER Flores, Adolfo. La Carlota en los relatos de viajeros y escritores de los siglos XVIII y XIX. Madrid: Bubok Publishing, 2009, p. 45).

20. AHN, Inquisición, leg. 1866, pieza 2, testigo 67 (Francisco de la Coba, 1776).

21. AHN, Inquisición, leg. 1866, pieza 2, testigo 46 (fray Romualdo de Friburgo, 1775); pieza 3, testigo 138 (Antonio Capmany, 1777).

22. AHN, Inquisición, leg. 1866, pieza 3, testigo 141 (Juan Lanes y Duval, 1777).

23. Hamer Flores, Adolfo. "Las Nuevas Poblaciones de Andalucía a finales del siglo XVIII según el Diccionario Geográfico-Histórico de Tomás López». Ámbitos. Revista de Estudios de Ciencias Sociales y Humanidades, 2005, 14, p. 98. 
En lo que respecta a las colonias dependientes de estas dos capitales, no disponemos de testimonios que nos permitan afirmar que los mercados que se celebraran en ellas también tuviesen el carácter de mercados francos semanales, pero sí hemos constatado la adecuación de espacios para comerciantes y mercaderes. Este es el caso de la parte baja del pósito de Aldeaquemada, que se arrendaba para tiendas de comestibles ${ }^{24}$, de los soportales edificados en la calle principal que daba acceso a la plaza mayor de Fuente Palmera o de la lonja de Carboneros, espacio que todavía continúa recibiendo este nombre, situado entre la parte trasera de la parroquia de la Inmaculada y el arrecife del camino real. Suponemos que seguirían el modelo impuesto desde las capitales, celebrándose durante los días festivos, pero su reducida extensión y la escasa capacidad de atracción de mercaderes forasteros dificultarían, sin duda, mantener una periodicidad fija e incluso que esas transacciones fueran rentables para foráneos; de ahí que básicamente constituyeran espacios de intercambio de productos locales.

Finalmente, la costumbre de emplear los días festivos para hacer públicas las sentencias e incluso para aplicar los castigos se consideró una práctica que irrespetaba la solemnidad de esas jornadas. En las ocasiones en las que se hubiera dictado una sentencia condenatoria, las autoridades neopoblacionales aprovechaban los domingos para encadenar a los condenados en una argolla situada en la plaza pública, facilitando así que todos los habitantes que iban a misa lo contemplaran y sirviera como mecanismo ejemplarizante y disuasorio ${ }^{25}$. Una práctica que, en líneas generales, no desentonaba con el modo de proceder en nuestro país y en otros Estados europeos en esta época, pues se consideraban útiles estas sentencias por aunar el carácter didáctico de lo que no debía hacerse con el castigo público por lo que se había hecho. En las nuevas colonias, la prioridad que se dio al trabajo y las limitaciones que Olavide impuso a la presencia de gran parte de los colonos en los núcleos urbanos principales en los días no festivos favoreció su uso en los que sí lo eran para advertir contundentemente de que el incumplimiento de las normas tenía consecuencias. De todos modos, no son muchas las referencias al empleo de esta práctica, que debió de limitarse a los casos más graves. Este fue el caso, por ejemplo, de las deserciones de colonos que, por el efecto llamada entre familiares y conocidos, tuvieron picos alcistas en distintos momentos entre $1768 \mathrm{y}$ 1771. Al establecerse como colonos, las familias se comprometían a no abandonar, sin permiso, sus bienes y las nuevas poblaciones durante diez años, aceptando ser castigados si incumplían lo acordado. No pueden extrañar, pues, casos como el que tuvo lugar en octubre de 1771, cuando Olavide afirmaba haber castigado

24. PÉREZ FERNÁNDEZ, Francisco José. Aldeaquemada. Riqueza territorial, industrial y comercial de 1813. Aldeaquemada: Centro de Estudios Neopoblacionales, 2015, p. 4.

25. LERA GARCía, Rafael de. "Conflictividad social en las Nuevas Poblaciones de Sierra Morena 1767-70». En AvilÉs, Miguel y SENA, Guillermo (eds.). Carlos III y las "Nuevas Poblaciones». Córdoba: Universidad de Córdoba, 1988, p. 53. 
a dos familias alemanas por haber desertado después de vender todos los granos que habían cogido en su suerte. A los hombres los expuso con argollas a la vergüenza pública y a las mujeres las remitió al hospicio de Jaén para corregirlas ${ }^{26}$.

\section{El MODELO DE OCIO POPUlar IMPUlSADO POR OlaVide EN LAS NuEVAS Poblaciones de Sierra Morena y ANDAlucía}

Las actividades de ocio público en la época que estudiamos estaban restringidas, en gran medida, a los días de fiesta; en los cuales también se desarrollarían otras prácticas privadas con los mismos fines ${ }^{27}$. No obstante, la oferta y variedad era muy limitada en un entorno rural como el que estudiamos, caracterizado por explotaciones agrarias diseñadas para mantener a una familia. Las tabernas se erigían así en el espacio más recurrente para una población masculina que experimentaba los rigores de la puesta en marcha de las colonias y el desarraigo por estar en un país con lengua, clima y costumbres muy diferentes a las de sus lugares de origen. Pablo de Olavide, consciente del "abuso que hacen estos extranjeros del vino, dándose mucho a la embriaguez", no dudó en estancar su venta en las colonias "para evitar desórdenes y sujetarlas en lo posible al buen gobierno ${ }^{28}$. Además, hizo lo posible para que la presencia de los colonos en ellas no se convirtiese en el principal entretenimiento en sus ratos de $\mathrm{ociO}^{29}$, poniendo limitaciones e incentivando otras actividades, destacando sobremanera los bailes. Es por ello por lo que el superintendente ordenaba que los colonos que acudían los domingos y días festivos desde las aldeas y departamentos no pudieran

26. Palacio ATARD, Vicente. Los españoles de la Ilustración. Madrid: Ediciones Guadarrama, 1964, p. 193.

27. Algunas de ellas, como la caza, requerirían autorización mientras que otros encuentros privados para jugar, beber y divertirse solo debían gestionarse evitando grandes concentraciones de personas.

28. AHN, Inquisición, leg. 3602, s. f.

29. En este empeño, las autoridades de las Nuevas Poblaciones debieron enfrentarse al interés de las jurisdicciones aledañas por obtener ingresos, aunque contribuyeran a generar problemas, estableciendo tabernas en barracas próximas a las nuevas colonias. Este fue el caso, por ejemplo, de un punto de venta de vino levantado en 1771 en término de Écija, aunque inmediato al lugar principal de la feligresía de La Luisiana, con el objetivo de que sus vecinos tuvieran fácil acceso a esta bebida. La respuesta de Olavide no se hizo esperar, logrando del rey una real orden en enero de 1772 que le permitía retirar las tabernas que considerase perjudiciales para las nuevas colonias, aunque no estuvieren dentro de su término. De este modo, aunque con cierta reticencia por parte de las autoridades astigitanas, en mayo de 1772 el punto de venta de vino antes mencionado quedó clausurado (AHN, Inquisición, leg. 3602, s. f.). 
permanecer en La Carolina ${ }^{30}$ después de asistir a la misa mayor, con lo cual evitaba la tentación de que permaneciesen durante horas en las mencionadas tabernas ${ }^{31}$.

Una prohibición que nunca constituyó un procedimiento extremo para impedir malos comportamientos generalizados ${ }^{32}$, sino fundamentalmente un mecanismo para reorientar las actividades de ocio hacia un resultado más beneficioso para la sociedad. No se limita el acceso a las tabernas o se prohíben los bailes y fiestas privadas multitudinarias ajenas al control de la Administración porque los colonos tengan una tendencia irrefrenable a emborracharse y causar desórdenes, sino para evitar que esos comportamientos puntuales se extiendan en un entorno que lo facilitaría por los rigores de los primeros años y por no contar con muchos otros espacios de diversión diferentes. El superintendente tratará de dar un giro copernicano al modelo de ocio popular, trasladando al espacio público un modo distinto de practicar la sociabilización, de ahí la lógica resistencia social de quienes no compartían esas prácticas y las presiones de las autoridades para que los colonos asistieran.

\subsection{Los bailes y la influencia de Olavide}

Las enormes dificultades de los primeros momentos, en los que todo estaba por hacer, impidieron a Olavide poner en marcha, antes de finales de 1768, los bailes públicos según el modelo que tenía pensado. En un territorio montuoso, con colonos viviendo en barracas provisionales mientras se construían sus casas y donde era necesario erigir prácticamente desde cero casi todos los núcleos urbanos y sus equipamientos, incluso el disponer de espacios adecuados para esos bailes requirió un tiempo. De todos modos, los beneficios que estos reportaban como elementos favorecedores de la tranquilidad y cohesión social, pues permitían sobrellevar mejor los difíciles momentos iniciales, hicieron que la Administración los fomentase y regulase desde muy pronto. Solo cinco meses después de iniciarse la colonización en Sierra Morena y cuando todavía no habían llegado ni la mitad de los vecinos que se establecerían en este territorio, el subdelegado Miguel de Jijón nos describe el papel que tendría la autoridad en dichas fiestas y cómo las promocionarían entre la población cuando propuso al Consejo de Castilla una

30. Esta costumbre, sin duda, se extendería a las restantes capitales de feligresía de las nuevas colonias.

31. AHN, Inquisición, leg. 1866, pieza 3, testigo 101 (Jerónimo de Guillenea, 1777).

32. Los primeros años de la colonización nos ofrecen no pocos testimonios acerca de que los colonos se gastaban o perdían sus haciendas y cosechas emborrachándose y jugando. Unas generalizaciones en las que habitualmente existe un desigual maridaje, en función de cada testimonio, entre xenofobia, oposición al proyecto y casos reales. Así pues, mientras que los detractores de la colonización ofrecen descripciones en las que detectar cualquier rasgo positivo es casi imposible, los testimonios de los promotores y partidarios inciden más en describir cómo las malas prácticas se extienden si no se actúa para remediarlo. 
ordenanza de policía para las Nuevas Poblaciones de Sierra Morena, fechada en 7 de enero de 1768, en la que entre otros puntos también se regulaba el esparcimiento de sus habitantes. Nacía así el germen de lo que pocos meses después se consolidaría en La Carolina por intervención directa del superintendente. En este texto se daba especial importancia al papel de los alcaldes pedáneos, con autoridad para establecer dichos bailes en cada uno de sus pueblos, pudiendo construir incluso «un circo o anfiteatro» para su realización en las plazas públicas, tal y como después se realizó en la capital. El reglamento especificaba que se realizarían los domingos y días de fiesta, después de cumplir con las obligaciones de la iglesia, "para que en él juntos y congregados como amigos y buenos vecinos, logren el desahogo de las tareas de la semana» ${ }^{33}$.

Con esta ordenanza el subdelegado Jijón nos muestra una de las funciones principales de las plazas de las nuevas colonias, el ocio, que si bien hasta la fecha había quedado insinuado ahora queda claramente especificado por parte de la autoridad neopoblacional. No podemos obviar, en este sentido, el hecho de que la mayoría de Nuevas Poblaciones construidas se dotaran de plazas públicas, espacios que durante estos primeros años se iban a cuidar y fomentar por parte de la Superintendencia como lugares de cohesión social, donde los colonos se divirtieran bajo la atenta mirada de las autoridades civiles. Actividades en las que la música tuvo, sin ningún género de duda, un papel medular. Los datos que poseemos en este sentido, paradójicamente, son muy parcos para los primeros años de la colonización; algo que no nos impide afirmar que se produjo y fomentó una interesante mezcolanza derivada de la considerable heterogeneidad de la población, en la que se combinaban familias originarias de distintos territorios centroeuropeos y de varias regiones españolas. Entre ellas hubo algunos individuos que tocaban un amplio espectro de instrumentos musicales, lo cual facilitó enormemente el disponer del necesario acompañamiento sonoro en los bailes ${ }^{34}$.

33. AHN, Inquisición, leg. 3601, exp. 6, f. 232. Miguel de Jijón a Ignacio de Higareda. La Peñuela, 7 de enero de 1768. PÉREZ FERnÁNDEZ, Francisco José. Colonos y propietarios de las Nuevas Poblaciones de Sierra Morena durante la Edad Moderna (Tesis doctoral inédita). Universidad de Jaén, 2019, p. 187.

34. El tema de la música en las Nuevas Poblaciones de Sierra Morena y Andalucía ha sido escasamente tratado por la comunidad científica, de ahí que dispongamos de pocas investigaciones. Entre ellas destacan las publicaciones de PÉrez Fernández, Francisco José. Cancionero Popular de Aldeaquemada. Folclore de las Nuevas Poblaciones de Sierra Morena. Jaén: Diputación de Jaén, 2015; "Algunas notas sobre la música culta en las Nuevas Poblaciones de Sierra Morena». Boletín del Centro de Estudios Neopoblacionales, 2016, 9-10, pp. 35-52, y «Música y folclore en las Nuevas Poblaciones de Sierra Morena y Andalucía: estado de la cuestión y nuevas líneas historiográficas”. Revista de Historiografía, 2018, 29, pp. 313-328. También conviene resaltar el trabajo de MARín LóPEZ, Javier. «Cultura musical y Nuevas Poblaciones». En TARIFA Fernández, Adela; Fílter Rodríguez, José Antonio y Ruiz Olivares, Amparo (coords.). Congreso Internacional Nuevas Poblaciones de Sierra Morena y Andalucía y otras colonizaciones agrarias en la Europa de la Ilustración. Jaén: Diputación de Jaén, 2018, pp. 1523-1547. 
El origen de la plaza que se construyó con el objetivo de servir para los bailes públicos en la capital de Sierra Morena se encuentra en junio de 1768, momento en el que el superintendente encomendó al mencionado Miguel de Jijón que se construyese, en el lugar que le había señalado, una plaza con asientos de piedra que pudiese servir a los colonos para tener en ella sus bailes públicos y evitar el desorden y embriaguez que ya se estaban introduciendo en sus barracas ${ }^{35}$. El subdelegado cumplió las órdenes inmediatamente, con lo que se sumó un nuevo espacio urbano a la localidad situado al sur de la plaza mayor o de la iglesia ${ }^{36}$ que, poco después, sería conocido como lonja o plaza de los Mesones. El recinto, convenientemente delimitado por un muro de piedra con tres órdenes de gradas rematadas con pirámides pequeñas, tenía capacidad para «más de mil espectadores sentados y dos mil en pie ${ }^{37}$, habiéndose aprovechado además para levantar en él dos torres conmemorativas, a las que se dotó de relieves e inscripciones, que flanquearan la entrada al núcleo urbano ${ }^{38}$.

Los datos que poseemos sobre estos bailes públicos son escasos y fragmentarios, lo cual no impide que podamos alcanzar una idea cabal acerca de cuándo y cómo se celebraban, o conocer los principales argumentos de sus detractores. Vigentes desde 1768 hasta la primavera de 1776, momento en el que dejaron de celebrarse, tenían lugar los días de fiesta por la tarde después de Vísperas y hasta el toque de oración ${ }^{39}$ durante dos épocas del año: desde el día de la Inmaculada Concepción hasta el último día de Carnestolendas y desde el día siguiente de finalizar la Cuaresma hasta el Corpus Christi o San Juan. Se suspendían, pues, durante la Cuaresma y mientras duraban las labores relacionadas con las cosechas y las siembras $^{40}$. Resulta muy significativo que, a diferencia de los bailes de los departamentos, que se celebraban tras la misa mayor (habitualmente realizada antes del mediodía), este baile público de la capital tuviera lugar en horario nocturno. Una circunstancia que facilitó, sin duda, los propósitos de Olavide de que sirviera de incentivo a la sociabilidad y a la aparición de nuevas parejas, y que fue factible gracias a la presencia de autoridades que podían frenar cualquier altercado potencial.

35. AHN, Inquisición, leg. 4210. Carta de Pablo de Olavide a Miguel de Múzquiz, 12 de junio de 1769 .

36. También conocida como plaza del Palacio.

37. El Archivo Histórico Nacional conserva entre sus fondos un dibujo realizado en junio de 1769 que nos muestra cómo era esa plaza y nos aporta algunas informaciones sobre las torres conmemorativas (AHN, Inquisición, MPD n. ${ }^{\circ}$ 57).

38. Estas dos torres se conservan todavía en La Carolina, aunque no en su ubicación original ya que fueron trasladadas al inicio del paseo del Molino de Viento en el siglo XIX.

39. Se conoce como Vísperas al oficio divino verpertino que se realizaba al anochecer, por lo que su celebración tenía lugar habitualmente a la luz de las lámparas. Por su parte, el toque de oración debe de hacer referencia a las Completas, que tenían lugar unas tres horas más tarde y que marcaban el momento de dirigirse al descanso nocturno.

40. AHN, Inquisición, leg. 1866, pieza 3, testigo 79 (fray Carlos Frey, 1776) y testigo 141 (Juan Lanes y Duval, 1777). 
Tan convencido estaba de sus beneficios que, décadas más tarde, no dudó en afirmar en El Evangelio en triunfo que "para divertir y ocupar la juventud con decencia convendría establecer [en las tardes de los días festivos] un baile público, que por lo mismo de ser público y de que asistirán los ancianos y magistrados, no puede dejar de ser decente ${ }^{41}$; es más, en su novela La familia feliz hizo que el protagonista, un joven que regresa a su pueblo tras haberse formado y viajado por Europa, conociera a su futura esposa en el baile público que se celebraba el domingo después de vísperas:

Allí concurría toda la juventud del lugar, y allí bailaban las jóvenes mujeres con los mozos, dándose un rato de recreación, que no podía dejar de ser decente porque era pública y se hacía a la vista de los padres y las madres. Ricardo, que conocía esta costumbre, fue con gusto [...]. Su corazón estaba conmovido con un placer tierno, y comparaba esta amable simplicidad de una diversión tan alegre y festiva con la estudiada y afectuosa vanidad de los bailes del mundo ${ }^{42}$.

Los recursos que Olavide empleó para garantizar la asistencia de los colonos a estos bailes públicos de las colonias fueron muy variados. Entre los más destacados podemos mencionar la prohibición de que simultáneamente se celebrara otra actividad lúdica y las presiones del superintendente para que aquellos se sintieran obligados a asistir. Ni que decir tiene que en función de la mayor o menor atracción que esta celebración tuvo en los asistentes se vivieron esos apremios de manera muy diferente. El clero, especialmente fray Romualdo de Friburgo, sostenía que Olavide amenazaba a los colonos con llevarlos a la cárcel si no asistían, haciendo que hasta los niños estuvieran presentes ${ }^{43}$, mientras que los vecinos de la localidad se distribuían entre los que seguían las tesis de los eclesiásticos ${ }^{44}$ y los que nunca tuvieron noticias de esas presiones o no las percibieron como tales ${ }^{45}$. Durante los dos primeros años, al objeto de facilitar la afluencia de personas, se dispuso que, después de misa mayor, un catalán fuese por las calles de la capital tocando el tamboril y la flauta; labor que se reforzó tiempo después con la incorporación de otro catalán que llevaba una gaita gallega. Una tarea para la que

41. El fragmento en el que Olavide defiende estos bailes públicos semanales formaba parte de la Carta XXXIX de la obra, pero no fue incluido en la versión impresa de 1797-1798. Por suerte, el hecho de haberse conservado el manuscrito de la obra nos permite conocer su contenido (Dufour, Gérard. Cartas de Mariano a Antonio. El programa ilustrado de El Evangelio en triunfo. Provence: Université de Provence, 1988, p. 232).

42. CÉSPEDES y MonRoy, Atanasio. Lecturas útiles y entretenidas. Lectura veinte y nueve. La familia feliz. Parte Primera. Madrid: En la Oficina de Dávila, 1817, pp. 8-9. Atanasio Céspedes fue uno de los pseudónimos utilizados por Pablo de Olavide.

43. AHN, Inquisición, leg. 1866, pieza 2, testigo 46 (fray Romualdo de Friburgo, 1775) y testigo 67 (Francisco de la Coba, 1776); pieza 3, testigo 82 (Francisco Antonio Henseler, 1776).

44. AHN, Inquisición, leg. 1866, pieza 3, testigo 100 (Juan Adam Spies, 1777).

45. AHN, Inquisición, leg. 1866, pieza 3, testigo 110 (Francisca Hurtado, 1777) y testigo 101 (Jerónimo de Guillenea, 1777). 
también daban vueltas en la plaza de la iglesia ${ }^{46}$, con el evidente objetivo de atraer a aquellos que estuvieran en misa. Aún más, sabemos que hasta 1771, para dificultar que los que salían de misa se marchasen a sus casas, «algunos colonos músicos [entraban] al atrio de la iglesia, aguardando con sus instrumentos que salieran de las Vísperas para ir al baile público ${ }^{47}$. Por otro lado, para evitar que los colonos extranjeros que vivían fuera del lugar principal faltaran al evento se encomendó a Sebastián Steiner, intérprete de la Superintendencia, que les persuadiese en este sentido ${ }^{48}$.

Además de la lógica presencia, por cuestiones de seguridad, del alguacil mayor, acudían al evento las autoridades civiles y las de carácter militar que se encontrasen en el lugar. La presencia de Olavide y del alcalde mayor eran habituales $^{49}$, mientras que la de los alcaldes pedáneos de la localidad era obligatoria bajo pena de diez reales por cada ausencia que no se pudiera justificar ${ }^{50}$. No obstante, el deseo de combatir la oposición de la mayor parte de los eclesiásticos a esta celebración llevó al superintendente a insistirles en que estuvieran presentes para que, con su asistencia, los colonos dejasen de pensar que era una actividad pecaminosa. Iniciativa bastante exitosa pues todos los religiosos, a excepción de fray Romualdo de Friburgo, estuvieron presentes en alguna ocasión ${ }^{51}$. Es probable que la circunstancia de que los salarios del clero fuesen pagados en las nuevas colonias por la Real Hacienda condicionara bastante esa decisión de estar presentes. No tenemos datos acerca de las cifras de asistentes, pero debieron de ser muy considerables pues sabemos que, a pesar de la gran capacidad de las gradas, existía la costumbre de llevarse escaños para sentarse ${ }^{52}$. Incluso el mencionado capuchino se quejaba porque se sacaban los bancos del interior de la iglesia para llevarlos hasta esta plaza ${ }^{53}$.

En lo que respecta al baile en sí, nos consta que se incentivó la abundante presencia de músicos con distintos instrumentos mediante el pago, por parte de la Contaduría, de una peseta por cada día que tocaban allí. Una medida que tuvo como consecuencia negativa la dificultad con la que se encontraron los eclesiásticos para que aquellos quisieran tocar en las funciones religiosas, pues por estas no cobraban. Además, se evitaba que los presentes permanecieran en la plaza

46. AHN, Inquisición, leg. 1866, pieza 3, testigo 141 (Juan Lanes y Duval, 1777).

47. AHN, Inquisición, leg. 1866, pieza 2, testigo 56 (Pedro de Vera, 1775). También nos informa de esto mismo el colono Juan Adam Spies (pieza 3, testigo 100).

48. AHN, Inquisición, leg. 1866, pieza 2, testigo 67 (Francisco de la Coba, 1776).

49. AHN, Inquisición, leg. 1866, pieza 3, testigo 101 (Jerónimo de Guillenea, 1777).

50. AHN, Inquisición, leg. 1866, pieza 3, testigo 100 (Juan Adam Spies, 1777). Este colono había sido alcalde pedáneo del Departamento $1 .^{\circ}$ de La Carolina durante los tres primeros años de existencia de los bailes públicos, de ahí que conociese bastante bien esta obligación. También nos da cuenta de la cuantía de esta multa el capuchino alemán fray Romualdo de Friburgo (pieza 2, testigo 46).

51. AHN, Inquisición, leg. 1866, pieza 2, testigo 56 (Pedro de Vera, 1775).

52. AHN, Inquisición, leg. 1866, pieza 3, testigo 109 (Diego Vicente Portichuelo, 1777).

53. AHN, Inquisición, leg. 1866, pieza 2, testigo 46 (fray Romualdo de Friburgo, 1775). 
sin participar en los bailes y, por consiguiente, poniendo en riesgo el éxito de la actividad. Todos recibían una clara indicación de que debían bailar y no solo quedarse sentados o como meros espectadores de bailes ajenos ${ }^{54}$.

La necesidad de que los asistentes se sintieran cómodos hizo inviable la imposición de un modelo homogéneo de celebración, de ahí que esta mostrara tanta heterogeneidad como la propia sociedad neopoblacional visualizaba entonces. No puede extrañarnos, por tanto, que algún testigo nos informe de que «esos bailes eran en francés, alemán, catalán y español, ${ }^{55}$. Distintas formas de bailar que no siempre contaron con el beneplácito de otros asistentes. En este sentido, parece que la que mostraban los alemanes era la que más escandalizaba a los españoles ${ }^{56}$, pues los hombres cogían a las mujeres con sus manos por debajo de los brazos, las cambiaban de lugar y las levantaban ${ }^{57}$. No obstante, lo que molestaba sobremanera a muchos asistentes, sobre todo a los clérigos, era la indumentaria de las mujeres, ya que, siguiendo los deseos de Olavide, acudían con el pelo arreglado y descubierto y sin cubrirse hombros y pecho con pañuelos ${ }^{58}$. Al parecer, su intención era imitar la moda francesa, habiendo llegado el superintendente a hacer peinar y vestir "a la francesa" a una joven lavandera que estaba al servicio de su casa, mostrándose en público con ella ${ }^{59}$. Además, parece que en alguna ocasión incluso se procedía a rotar la pareja de baile, dando lugar a que mujeres casadas bailaran con otros hombres tanto solteros como casados ${ }^{60}$. Tan alejado estaba de lo habitual este modo de proceder que no solo algunos eclesiásticos locales no volvieron a acudir una segunda vez, escandalizados por las referidas vestimentas ${ }^{61}$, sino que varios forasteros que presenciaron esos bailes públicos a su paso por La Carolina no dudaron en calificarlos como "bailes deshonestos" ". Visión que no compartían todos aquellos colonos y colonas que participaban gustosos en ellos, ya que la actividad les permitía divertirse.

En este sentido, entre los colonos no faltaron los férreos defensores de este modelo de baile impulsado por Olavide. Hasta tal punto que lo replicaron a nivel privado a pesar de las restricciones existentes y de que, como cabía esperar, ello dio lugar a algunos problemas. Veamos un ejemplo. El día de Reyes de 1776, el colono Domingo Martínez, alcalde pedáneo del Departamento $1 .^{\circ}$ de La Carolina,

54. AHN, Inquisición, leg. 1866, pieza 2, testigo 46 (fray Romualdo de Friburgo, 1776); pieza 3, testigo 79 (fray Carlos Frey, 1776).

55. AHN, Inquisición, leg. 1866, pieza 3, testigo 100 (Juan Adam Spies, 1777).

56. AHN, Inquisición, leg. 1866, pieza 3, testigo 110 (Francisca Hurtado, 1777).

57. AHN, Inquisición, leg. 1866, pieza 3, testigo 109 (Diego Vicente Portichuelo, 1777).

58. AHN, Inquisición, leg. 1866, pieza 2, testigo 56 (Pedro de Vera, 1775).

59. Defourneaux, Marcelin. Pablo de Olavide, el afrancesado. México: Editorial Renacimiento, 1965 , p. 183.

60. AHN, Inquisición, leg. 1866, pieza 2, testigo 46 (fray Romualdo de Friburgo, 1776).

61. AHN, Inquisición, leg. 1866, pieza 2, testigo 67 (Francisco de la Coba, 1776).

62. AHN, Inquisición, leg. 1866, pieza 1, testigo 44 (José Antonio de Losada, 1776). Carlos de Silva narró, una vez que llegó a Sevilla, todo lo que había visto en La Carolina a José Antonio de Losada. 
organizó un baile privado en su casa. Sabedor de que su vecino Cristóbal Hoggenfus, colono alemán, nunca permitía a sus hijas que fueran al baile público, aguardó a que este y su mujer se durmieran para llamar a las hijas de Hoggenfus a su casa para que bailasen. Al día siguiente, el alemán reprendió a su vecino por haber obrado contra su voluntad, pero solo obtuvo como respuesta que ellos como cristianos bailaban en sus fiestas pues no eran judíos como los alemanes, que evitaban bailar los sábados. Una afirmación que pretendía, a la vez que provocar, cuestionar el modo de entender la religiosidad de una familia que se encontraba entre los más cercanos seguidores de fray Romualdo de Friburgo, sin duda el mayor opositor a los bailes impulsados por Olavide. El capuchino alemán, mucho más rígido en sus principios que los eclesiásticos españoles, consideraba que no se debían "sembrar amores fornicarios y adulterinos con bailes, y menos con bailes públicos por ser estos mucho más peligrosos", alentando siempre a sus seguidores para que no participasen ${ }^{63}$.

\subsection{Una actividad para la élite: máscaras y teatro}

Como contrapunto a los bailes, parece que Olavide también impulsó en La Carolina, en esos días festivos, la realización de "máscaras y comedia" ${ }^{64}$. No obstante, la circunstancia de que solo fray Romualdo de Friburgo nos hable de ellas nos hace pensar que quizá se trató de actividades puntuales y elitistas organizadas por el superintendente, solo para sus familiares e invitados selectos, en las largas temporadas que tuvo que permanecer alejado de Sevilla en su palacio de la capital de las colonias de Sierra Morena. Un tiempo en el que debía prescindir, por tanto, de su amado teatro ${ }^{65}$, al que asistía con frecuencia mientras permanecía en aquella ciudad. Casi desde su toma de posesión como asistente mostró en la capital hispalense su gusto por los bailes de máscaras en Carnaval, enfrentándose a los que predicaban contra ellos ${ }^{66}$ y a parte de la oligarquía local que los consideraba, al igual que al teatro, como algo poco recomendable ${ }^{67}$. No puede perderse de vista tampoco que el levantamiento de la prohibición de representar comedias en la ciudad y reino de Sevilla había tenido lugar por real resolución de 12 de abril de 1767, trasladada por carta-orden del Consejo de

63. AHN, Inquisición, leg. 1866, pieza 2, testigo 46 (fray Romualdo de Friburgo, 1776).

64. AHN, Inquisición, leg. 1866, pieza 2, testigo 46 (fray Romualdo de Friburgo, 1775).

65. Para una aproximación más detallada al teatro en el siglo XVIII es recomendable la consulta de ANDIOC, René. El teatro en el siglo XVIII. Madrid: Taurus, 1982, y Teatro y sociedad en el Madrid del siglo XVIII. Madrid: Castalia, 1988.

66. AHN, Inquisición, leg. 1866, pieza 2, testigo 49 (Antonio Torrado, 1775) y testigo 52 (Romualdo Castro, 1775). En una conversación que Pablo de Olavide mantuvo en enero de 1769 con alguna persona de la que no pueden precisar el nombre, al mencionarse que un predicador había hablado mal del baile de máscaras, el asistente dijo que lo iba a mandar sacar de la ciudad.

67. AHN, Inquisición, leg. 1866, pieza 2, testigo 58 (Domingo Rivero, 1775). 
Castilla de 7 de julio, por lo que las decisiones de Olavide se combinaron con no estar acostumbrados los asistentes a algunos contenidos ${ }^{68}$.

En cualquier caso, poco parecieron importar estas opiniones a nuestro personaje, que no dudó en regular las representaciones teatrales en Sevilla mediante dos reglamentos fechados en $1767^{69}$, en elaborar y publicar en 1768 un reglamento sobre los bailes de máscaras ${ }^{70}$ y en promover la construcción de un coliseo o teatro para el que también fundó una escuela o colegio ${ }^{71}$. Las habladurías y escándalos no tardaron en llegar debido a que Olavide insistía en que la población asistiera a estos eventos porque así lo disponía el Gobierno. Es probable que tuviese la esperanza de que, poco a poco, la sociedad sevillana se aficionaría a ellos; no obstante, nada más lejos de la realidad. Aunque representaron cientos de obras de Molière, Racine y otros franceses, lo cierto es que más de la mitad de ellas no pasó de las cuatro representaciones. Las más exitosas, como era de esperar, fueron obras como El diablo predicador del sevillano Luis Belmonte Bermúdez, No puede ser guardar una mujer del madrileño Agustín Moreto o El príncipe tonto del malagueño Francisco de Leiva ${ }^{72}$. A diferencia de las élites intelectuales ilustradas, el pueblo se mantuvo fiel a los gustos tradicionales.

En cuanto a la institución destinada a fomentar el teatro y formar actores y actrices para su representación, también tuvo problemas con las obras representadas y por el comportamiento de su director. Aunque Olavide trató de que las obras de teatro a representar pasasen una censura que lo descargase de divulgar cualquier proposición herética, en 1772 se representaron varias que disgustaron a los asistentes, llegando incluso alguna de ellas a no representarse más de una vez por haber recibido silbidos de desaprobación del público ${ }^{73}$. Pero por si eso no era poco, la mujer de monsieur Reynaud, director de la mencionada escuela de teatro, se separó de su marido y una de las cómicas de su compañía, llamada la Bermeja, tuvo un hijo con este. No debe extrañar, por tanto, que Francisco de

68. Carta-orden del Consejo de Castilla de 7 de julio de 1767 y decreto de la Audiencia de Sevilla de 13 de julio de 1767, impresos en Sevilla el 21 de julio de ese mismo año (Archivo Personal de Adolfo Hamer).

69. Olavide, Pablo de. Plan de estudios para la Universidad de Sevilla. Madrid: Ediciones de Cultura Popular, 1969, p. 23.

70. AHN, Inquisición, leg. 1866, pieza 3, testigo 107 (Francisco Fernández de las Peñas, 1777).

71. AHN, Inquisición, leg. 1866, pieza 3, testigo 140 (Manuel Lázaro de la Vega, 1776). Este nuevo teatro empezó a construirse en una esquina de la plaza del Duque, pero no se terminó, levantando otro provisional de madera y ladrillo en la calle San Eloy que finalmente estuvo funcionando durante doce años [Bejarano Pellicer, Clara. "Sociabilidad, música y danza en el siglo XVIII». En FerNÁNdez Cortizo, Camilo; Migués Rodríguez, Víctor Manuel y Presedo Garazo, Antonio (eds.). El mundo urbano en el siglo de la Ilustración. IX Reunión Científica de Historia Moderna. Santiago de Compostela: Xunta de Galicia, 2009, vol. 1, p. 299].

72. Aguilar Piñal, Francisco. Sevilla y el teatro en el siglo XVIII. Oviedo: Universidad de Oviedo, 1974, pp. 124-125.

73. Se trató de una obra traducida del inglés y titulada El buérfano. 
Bruna, oidor de la Real Audiencia de Sevilla, acabara remitiendo esa compañía de teatro a Madrid para acabar con los escándalos y quejas ${ }^{74}$. El rechazo a la obra de Olavide no quedó ahí pues por una real orden de marzo de 1779, cuando ya era nuevo asistente de la ciudad Francisco Antonio Domezain, el monarca accedió a las peticiones recibidas desde la ciudad y suspendió las aficiones teatrales, los bailes públicos e incluso las veladas o festejos que se celebraban en las vísperas de algunas festividades religiosas ${ }^{75}$.

Esos bailes de máscaras debemos contextualizarlos en línea de las reformas que propició el conde de Aranda ${ }^{76}$, el cual se encargó de organizar los que se celebraron en los Teatros del Príncipe y los Caños del Peral de Madrid entre 1767 y 1773 para las clases altas exclusivamente ${ }^{77}$. Pero todo apunta a que o bien Olavide actuó con menos prudencia o la sociedad sevillana no era tan permisiva como la madrileña, pues los bailes de máscaras de 1773 dieron mucho que hablar en la ciudad de Sevilla por haberse visto en ellos «deshonestas desnudeces» y

74. AHN, Inquisición, leg. 1866, pieza 3, testigo 152 (José de la Iglesia, 1777). Louis de Assoma Reynaud, en el que Olavide valoraba la capacidad para declamar bien en francés y saber español, se encargó del adiestramiento de los hombres, mientras que de la formación de las mujeres se ocupaba Ana de Marsari [Barrera, Trinidad y Bolaños, Piedad. "La labor teatral en Sevilla del peruano Pablo de Olavide». En Torres Ramírez, Bibiano y Hernández Palomo, José (eds.). Andalucía y América en el siglo XVIII. Actas de las IV Jornadas de Andalucía y América. Sevilla: CSIC, 1985, p. 33].

75. Moreno Mengíbar, Andrés. "Los orígenes de la ópera en Sevilla. La actuación de Olavide (1767-1779)". Archivo Hispalense, 1989, 221, pp. 17-32.

76. Esto explica que en otros muchos lugares de la Corona encontremos un impulso del teatro en esos años. A modo de ejemplo, en Córdoba, una ciudad muy próxima a algunas de las nuevas colonias, donde las críticas clericales lograron el cierre de su casa de comedias en 1695 y la demolición del edificio en 1734, se volvió a impulsar esta actividad en 1769 cuando su Ayuntamiento aceptó la petición de un italiano para construir un teatro para representar óperas italianas y españolas de música y baile aprobándose ese mismo año un reglamento. No obstante, aunque se dejaba atrás una larga etapa en la que el público solo pudo asistir a representaciones dramáticas de tipo religioso promovidas por la Catedral y por el colegio de los jesuitas, existió siempre gran prevención por parte de las autoridades para que no se representase ninguna comedia (CuADro GARCíA, Ana Cristina. La época de la Ilustración en Córdoba. Córdoba: Universidad de Córdoba, 2007, pp. 99-103). Tampoco la ciudad de Écija, de la que se tomaron extensos baldíos para conformar las nuevas colonias de Andalucía, se quiso quedar atrás en la cuestión del teatro. Tras numerosas peticiones, logró en 1763 del Consejo de Castilla la autorización para poder llevar a cabo representaciones, acometiendo desde 1767 una reforma integral del antiguo patio de comedias; labor nada fácil por su elevado coste. De ahí que en 1772 uno de sus regidores, el marqués de Peñaflor, solicitase a Olavide su apoyo ante el referido Consejo para poder terminar ese coliseo de comedias mediante ingresos de propios y arbitrios [Defourneaux, Marcelin. Pablo de Olavide, el afrancesado. México: Editorial Renacimiento, 1965, pp. 213-214; Bolaños Donoso, Piedad. "Un coliseo de comedias para la ciudad de Écija (1772)». En Álvarez Barrientos, Joaquín y Checa Beltrán, José (coords.). El siglo que llaman ilustrado. Homenaje a Francisco Aguilar Piñal. Madrid: CSIC, 1996, pp. 113-124].

77. Jovellanos, Gaspar Melchor de. Espectáculos y diversiones públicas. Informe sobre la Ley Agraria. Madrid: Cátedra, 1998, p. 179. Defourneaux, Marcelin. Pablo de Olavide, el afrancesado. México: Editorial Renacimiento, 1965, pp. 210-211. 
otras provocaciones ${ }^{78}$. Ello incluso a pesar de que previamente el asistente, como decíamos, había redactado un Reglamento para el bayle de máscaras en la ciudad de Sevilla en este carnaval de 1768. De este reglamento la Inquisición mandó quemar todos los ejemplares por calificar de censurable una frase que consideraba a los bailes de máscaras como "diversión honesta por sí misma»" A través de esta ordenanza reguló de forma muy exhaustiva su organización. La entrada costaba diez reales de vellón; la hora de finalización eran las doce de la noche; durante el baile solo se servían refrigerios, bizcochos y chocolate; se estipulaba que los disfraces debían estar relacionados con la Comedia dell'Arte y los trajes regionales, estando prohibido el travestismo, los disfraces de magistrados, religiosos o de clases bajas como gitanos; los tejidos utilizados debían estar hechos de lienzos lisos o pintados, holandillas, indianas de Cataluña o tafetanes, no pudiendo utilizarse materiales más nobles como telas de oro y plata, encajes, gasas, bordados, etc. Se prohibía usar las máscaras fuera del teatro, así como capas pardas, sombreros redondos, mantos y mantillas. Tampoco estaba permitida la introducción de armas blancas o de fuego en el baile. Los encargados de la vigilancia del teatro eran cuatro directores nombrados al efecto. En lo referido a la música del baile, se compondría de minuetos y contradanzas, nombrándose uno o más maestros de baile para que ordenaran las contradanzas y acomodaran las parejas. Finalmente, el baile era anunciado al público mediante carteles que se colocaban la víspera o el mismo día del evento por la mañana ${ }^{80}$.

No obstante, estos bailes, según los describe Olavide en su reglamento, estaban destinados a las clases altas, burguesía y aristocracia, y no eran aplicables a los colonos de las Nuevas Poblaciones. De hecho, formaban parte de una costumbre generalizada en nuestro país en esa época, de ahí testimonios tan elocuentes como el de Jovellanos en su Memoria sobre espectáculos y diversiones públicas, leída en la Real Academia de la Historia en 1796, que destacaba entre las diversiones para los ciudadanos o clases altas los saraos públicos, las academias dramáticas, las maestranzas o las máscaras, no permitidas en el momento de la redacción de su memoria, porque podían ser una fuente de ingresos para financiar los espectáculos permanentes en las capitales, a la par que evitarían el éxodo de la nobleza a la corte. Jovellanos se mostraba partidario de esta diversión, explicando que si se producían excesos gracias a la indulgencia que ofrecía el antifaz solo era por descuido de las autoridades, que en cualquier caso siempre podrían prohibir cubrir el rostro, permitiendo los disfraces honestos ${ }^{81}$. Todo ello nos permite concluir que, salvo en el entorno privado

78. AHN, Inquisición, leg. 1866, pieza 3, testigo 152 (José de la Iglesia, 1777).

79. Perdices De Blas, Luis. "Pablo de Olavide (1725-1803) a través de sus estudios». Cuadernos Dieciochistas, 2003, 4, p. 24.

80. Rico OsÉs, Clara. "La contradanza en España en el siglo XVIII: Ferriol y Boxeraus, Minguet e Yrol y los bailes públicos». Anuario Musical, 2009, 64, p. 208.

81. Jovellanos, Gaspar Melchor de. Espectáculos y diversiones públicas. Informe sobre la Ley Agraria. Madrid: Cátedra, 1998, pp. 195-196. 
del superintendente, estos bailes de máscaras no tendrían cabida entre familias extranjeras y españolas dedicadas fundamentalmente al mundo agrario y, en menor medida, a algunas actividades artesanales ${ }^{82}$.

\subsection{Otras manifestaciones de ocio popular: de los juegos a los toros}

Después de todo lo que hasta ahora hemos expuesto, es evidente que aquellos que no desearan asistir al baile público disponían en las nuevas colonias de pocas alternativas, más allá de quedarse en sus casas o de marcharse a otras poblaciones; decisión, esta última, que les obligaba a perderse los sermones y oficios religiosos, algo que también influiría para que algunos acudieran resignados al baile. Por suerte, la oferta de actividades impulsadas por el superintendente era más amplia, aunque no por ello generaba menos controversias. Teniendo como hora límite el inicio de la misa y el posterior baile, se autorizaron en los días festivos otras diversiones como el juego de bolear. Aún más, puntualmente la Superintendencia daba licencia para otros juegos ${ }^{83}$ o realizaba corridas de toros. En relación con esta última actividad, debemos destacar que una de las plazas erigidas en los inicios de La Carolina, aunque denominada de los Arcos, era conocida como la plaza de toros por ser el lugar donde se celebraban las corridas y novilladas ${ }^{84}$. Nos encontramos ante la primera plaza de forma octogonal construida en España con este fin, la cual estaba mejor adaptada a las faenas taurinas al prescindir de los habituales y peligrosos ángulos rectos usados hasta entonces.

La realización de esas corridas en las nuevas colonias, y fundamentalmente en La Carolina, durante los primeros años llamó la atención, máxime en un contexto en el que las colonias estaban iniciando su andadura, tanto de Giacomo Casanova $^{85}$ como de otros extranjeros que dieron noticias de esta actividad tan

82. PÉrez Fernández, Francisco José. Cancionero Popular de Aldeaquemada. Folclore de las Nuevas Poblaciones de Sierra Morena. Jaén: Diputación de Jaén, 2015, pp. 51-54.

83. Este fue el caso de un juego con la espada, destinado a recaudar dinero, autorizado por Pablo de Olavide en 1773 tras la petición de un anciano natural de Almagro y que era maestro en ese arte (AHN, Inquisición, leg. 1866, pieza 3, testigo 134: Jacinto Muñoz, 1777).

84. Esta plaza de forma octogonal servía, a la vez, para casa de vecinos y para la celebración de festejos taurinos. Un modelo que también se usó en otros lugares como Tarazona, que construyó su plaza octogonal con 24 casas en 1792, o Almadén, que levantó la suya con forma hexagonal (BONET CORREA, Antonio. Morfología y ciudad: urbanismo y arquitectura durante el Antiguo Régimen de España. Barcelona: Editorial Gustavo Gili, 1978, pp. 145-146).

85. «Era él [Olavide] quien conferenciaba con los ministros de Madrid para organizar esta población, proveerla de jueces que hiciesen justicia con rapidez, de curas, puesto que, como es lógico, todos estos suizos eran católicos, de un gobernador, de todos los oficios necesarios, de hacer construir casas, iglesias y sobre todo un teatro o circo para dar corridas de toros, espectáculo favorito en España, tan bello, tan humano, tan natural y tan razonable que los pensadores de este país no comprenden que haya en el mundo naciones que puedan prescindir de este espectáculo. Los buenos emigrantes de Suiza se encontraron, pues, en Sierra Morena con un basto (sic) anfiteatro para disfrutar 
llamativa para ellos. Una de las primeras menciones está fechada en 1774 cuando el inglés William Dalrymple, a su paso por La Carolina, se refirió de esta manera a su plaza: «[...] pero lo que señala bien la afición de ese país para las corridas de toros es que han construido un hermoso hexágono, únicamente destinado a hacer una plaza de toros ${ }^{86}$. Se integraban así en un entorno en el que, a fecha de 1768 , también se celebraban festejos anuales u ocasionales con toros de muerte en siete localidades jiennenses (Alcalá la Real, Castellar, Jaén, Navas de San Juan, Martos, Santisteban y Úbeda), en su mayoría con dehesas que permitían la existencia de ganaderías de reses bravas $^{87}$. Las colonias de Andalucía, por su parte, rara vez contaron con festejos taurinos, especialmente por la escasez del ganado necesario para ello, limitándose a eventos puntuales en los que se festejaba algún hecho o visita relevante. Este fue el caso de la estancia en La Carlota del arzobispo de Sevi$11 a^{88}$ mientras viajaba, en junio de 1799, hacia la capital hispalense. Después de ser recibido por las principales autoridades, de disfrutar de la comida que se ofreció en su honor y de visitar la iglesia, "toda aquella tarde estuvo su excelencia lleno de gozo, y lo mismo su señora hermana, por haber visto lidiar dos novillos con cuerdas que trajeron frente de su habitación, pues parece no habían visto jamás semejante diversión»" ${ }^{89}$.

Resulta muy llamativo que en el arte taurino las directrices de Olavide no vayan en línea con las ideas contrarias al toreo que se extienden en los círculos ilustrados. Tanto es así que no era una actividad que agradase a personajes muy cercanos al superintendente, y al propio proyecto neopoblacional, como Pedro

en determinados días de este delicioso espectáculo». En Casanova, Giacomo. Memorias de España. Barcelona: Áltera, 2001, pp. 91-92.

86. CAPel Margarito, Manuel. La Carolina, capital de las nuevas poblaciones. (Un ensayo de reforma socio-económica de España en el siglo XVIII). Jaén: CSIC e Instituto de Estudios Giennenses, 1970, p. 123; SÁNCHEZ MARTínEZ, Carlos. Datos para la historia antigua carolinense. La Carolina: Seminario de Estudios Carolinenses, 1982, p. 29; PÉREZ FERnÁNDEZ, Francisco José. Cancionero Popular de Aldeaquemada. Folclore de las Nuevas Poblaciones de Sierra Morena. Jaén: Diputación de Jaén, 2015, pp. 69-72. Este viajero indica que la plaza era hexagonal, computando tal vez solo el espacio construido, sumándose otros dos lados que aparecían al cerrar los dos accesos a esta.

87. Amigo VÁzQuez, Lourdes. «El escenario taurino. Plazas mayores y plazas de toros (siglos XVI-XVIII)». Andalucía en la Historia, 2015, 48, p. 11. Datos de la encuesta taurina de 1768.

88. Se trataba de Luis María de Borbón y Vallabriga, primo de Carlos IV y cuñado de Manuel de Godoy. Nacido en Cadalso de los Vidrios en 1777, gran parte de su juventud la pasó en la ciudad de Toledo junto a su preceptor el cardenal Lorenzana. Tras su ordenación como sacerdote en marzo de 1799, solo dos días después recibió el arzobispado de Sevilla y unos meses más tarde el nombramiento como cardenal de la Iglesia católica. A finales de 1800 fue promocionado al arzobispado de Toledo, aunque con el privilegio de retener la mitra de Sevilla en calidad de administrador (RoDríguez LóPEz-BREA, Carlos María. Dos Borbones, cardenales primados en Toledo. Cuenca: Universidad de Castilla-La Mancha, 2001, pp. 35-43).

89. Archivo General del Obispado de Córdoba -en adelante AGOC-, Despachos Ordinarios, caja 7117, atado 1, doc. 1. Carta del capellán mayor de La Carlota al obispo de Córdoba, 27 de junio de 1799 . 
Rodríguez de Campomanes, Miguel de Múzquiz o el conde de Aranda. En esta época, las suspensiones y prohibiciones de las actividades taurinas en España se sucedieron a intervalos, siendo refrendadas por la mayoría de los componentes del Consejo de Castilla, que veían en los toros un perjuicio económico por la reducción que causaban en las cabezas vacunas destinadas a las labores agrarias, y también humanitario por el trato que recibían los animales, toros y equinos, que se empleaban en la fiesta y el ambiente violento y de relajamiento de las costumbres que la rodeaba ${ }^{90}$. Las palabras de Feijoo, que sostenía que sería mejor dedicar los toros a labrar la tierra que a matarlos en la plaza, o las de Meléndez Valdés: «[...] el rudo gladiador que a sus pies deja / el útil animal que el corvo arado / para sí nos demanda", son muy ilustrativas de este sentimiento antitaurino; el cual alcanzaría su cénit con la figura de Jovellanos ${ }^{91}$.

Pese a esta corriente de pensamiento imperante en su círculo, el superintendente Olavide promoverá esas fiestas de toros, pues las utiliza como otro instrumento de ocio que puede servir para cohesionar a la heterogénea sociedad neopoblacional, al igual que los bailes. Algo que queda ratificado cuando fray Romualdo afirma que había interés en introducir los toros, algo que el capuchino consideraba un mal irremediable donde se había hecho siempre, pero no encontraba motivos para introducirlo en las nuevas colonias. A su juicio la actividad fomentaba las costumbres sangrientas y, además, era un contrasentido que en un lugar donde los colonos tenían prohibido dar limosnas incluso para las ánimas benditas, por ser mucho más beneficioso gastarlo en sus hogares, sí pudieran entregar ese dinero a los toreros ${ }^{92}$.

En cualquier caso, pese a las corrientes y opiniones contrarias, y en sintonía con lo ocurrido en el resto de España, las actividades taurinas se acabaron consolidando en las colonias de Sierra Morena y parece que nunca faltaban en las grandes celebraciones, como por ejemplo la que tuvo lugar el día dos de abril de 1820 en La Carolina ${ }^{93}$ o la organizada tres años más tarde cuando Fernando VII visitó esta colonia a finales de $1823^{94}$. No nos consta, en cambio, que estas corridas de toros o novilladas se realizaran con frecuencia en las Nuevas Poblaciones de Andalucía, muy probablemente por la práctica ausencia de dehesas en las que poder criar al ganado necesario y la imposibilidad de prescindir de unos escasos, caros y muy necesarios animales tan necesarios para el cultivo y transporte de productos.

90. Cossío, José María de. Los toros. Tratado técnico e histórico. Madrid: Espasa-Calpe, 1995, II, pp. 133-138.

91. JovelLanos, Gaspar Melchor de. Espectáculos y diversiones públicas. Informe sobre la Ley Agraria. Madrid: Cátedra, 1998, pp. 153-155.

92. AHN, Inquisición, leg. 1866, pieza 2, testigo 46 (fray Romualdo de Friburgo, 1776).

93. AlCÁZAr Molina, Cayetano. Las colonias alemanas de Sierra Morena. Madrid: Universidad de Murcia, 1930, p. 139.

94. AHN, Fondos Contemporáneos, Gobernación, leg. 2738, exp. 16. 


\subsection{La desaparición de la huella de Olavide}

Una vez detenido el superintendente por el Santo Oficio, muchas de las actividades de ocio que había impulsado con tanto interés se abandonaron con rapidez. Los bailes públicos de la plaza de los Mesones dejaron de realizarse después de la primavera de 1776, a la par que todas aquellas en las que participaban los colonos comenzaron a asemejarse a las existentes en cualquier localidad del entorno ${ }^{95}$. Poseemos referencias al juego de la barra o canto, que consistía en lanzar un trozo de hierro, en muchas ocasiones se utilizaba una reja de arado, a gran distancia. Una actividad en la que se produjeron algunos accidentes mientras se practicaba como, por ejemplo, cuando falleció un colono de la aldea de la Escolástica (Carboneros) al cruzarse en el momento de estarse realizando un lanzamiento en 1792, o cuando falleció un colono de Guarromán, en 1814, en similares circunstancias. En el caso de Aldeaquemada, la Intendencia de las Nuevas Poblaciones reclamó a su comandante civil un hierro que se habían dejado los albañiles y que los jóvenes utilizaban para el juego de la barra, lo que evidencia la popularidad de dicho juego y la preocupación que suscitaba entre las autoridades.

Junto a esos juegos también debemos destacar los naipes, pues existen referencias a arrestos relacionadas con partidas privadas; en las que las deudas contraídas por los jugadores llegaron a ser muy altas ${ }^{96}$. No es nada raro, pues, que las autoridades persiguiesen estas actividades como, por ejemplo, cuando en noviembre de 1780 el alguacil mayor, Juan Chavarri, tuvo aviso mientras realizaba su ronda de una partida de naipes a puerta cerrada en la sala alta de la casa del tejero Julián de Fuentes. Sorprendidos los participantes, fueron apresados y condenados por este delito el propio Julián de Fuentes, Ramón Alcaide y Miguel Zifuentes, vecinos de La Carolina, así como Manuel Moreno, que lo era de la de El Viso ${ }^{97}$. En el mismo año, Juan Moreno Camacho, encargado del mesón; Manuel Loaysa, sacristán, y Antonio del Campo, arrendador del abasto del vino, jugaron a la flor de veinte y cinco en Santa Elena. Fueron denunciados por la mujer del mesonero al comandante civil de dicha colonia, Álvaro de Ortega, por haber perdido su marido todo su dinero, por lo que fueron procesados por el subdelegado de

95. En 1801 el intendente Tomás José González Carvajal menciona algunas de estas actividades lúdicas restringidas en las colonias a los días de fiesta: juegos de bolos, pelota, barra, carreras, hoyuelo y rayuela (AHN, Consejos, leg. 4059, exp. 15).

96. SÁNCHEZ-BATALLA MARTÍNEZ, Carlos. La Carolina en el entorno de sus colonias gemelas y antiguas Poblaciones de Sierra Morena. Prebistoria a 1835. Jaén: Caja Rural de Jaén, 2000, II, pp. 272-273; PÉREZ FERnÁndez, Francisco José. Cancionero popular de Aldeaquemada. Folclore de las Nuevas Poblaciones de Sierra Morena. Jaén: Diputación de Jaén, 2015, pp. 269-270.

97. Archivo Histórico Municipal de La Carolina -en adelante AHMLC-, 2.3.8. Expedientes Procedimientos Civiles, años 1778-1785. Autos formados de oficio contra Julián de Fuentes, Ramón Alcaide, Miguel Zifuentes y Manuel Moreno, los tres primeros de este vecindario y el último de la villa del Viso, sobre juego de naipes. La Carolina, 1780. 
Sierra Morena Miguel de Ondeano ${ }^{98}$. Pero estas medidas disuasorias nunca fueron suficientes. En febrero de 1790, Mariano Arnoldt Wilt, encargado de la venta de géneros plomizos y naipes, decidió huir de La Carolina debido a las deudas contraídas por haber jugado varias noches a la flor envidada ${ }^{99}$. Además, la extracción social de los denunciados por los juegos de naipes era tan variada como la sociedad existente de las Nuevas Poblaciones, prueba de que todos los sectores participaban de este tipo de actividades, aunque estuviesen prohibidas las apuestas.

Los bailes, ciertamente, no desaparecerían por completo, pero la mayor parte quedaron ahora relegados al ámbito privado ${ }^{100}$, donde siempre habían existido coincidiendo con las principales festividades, y ajustándose a las costumbres tradicionales ${ }^{101}$. En este sentido, nos constan dos modalidades de estos en los años inmediatamente posteriores a la desaparición de Olavide: de un lado, los bailes realizados en domicilios particulares siguiendo una costumbre que databa de inicios de la colonización y, de otro, bailes de nuevo cuño vinculados al establecimiento de las primeras cofradías y hermandades. Entre los primeros, nos consta que el 22 de febrero de 1785, domingo de Carnestolendas, se organizó en la casa de Jorge Bernier, alcalde pedáneo del Departamento 2. ${ }^{\circ}$ de Navas de Tolosa, uno de estos bailes privados ${ }^{102}$. En cuanto a los segundos, en la Navidad de 1776 algunos colonos de Santa Elena, Arquillos y Navas de Tolosa, animados desde meses antes por el vicario Juan Lanes y Duval, recogieron algunas limosnas con el objetivo de establecer cofradías al Santísimo Sacramento y a las Ánimas ${ }^{103}$, para lo cual no dudaron en promover bailes en las dos primeras poblaciones, acompañados de instrumentos musicales, los cuales generaron una investigación inmediata por parte de las autoridades civiles. En ambos casos los colonos pujaban en esos bailes para bailar con las colonas, aunque en el caso de Santa Elena parece que

98. AHMLC, 2.3.8. Expedientes Procedimientos Civiles, años 1778-1785. Auto sobre naipes en Santa Elena, 3 de noviembre de 1780.

99. AHMLC, 2.3.8. Expedientes Procedimientos Civiles, año 1790. Autos formados sobre la fuga hecha por Mariano Arnol Wilt, a cuyo cargo estaba la Administración de Municiones y demás correspondientes a ella en esta capital. La Carolina, 1790.

100. En las festividades más importantes estos bailes y celebraciones, además de ser más frecuentes, también ocuparían parte del espacio público. El viajero francés Jean François Peyron, a su paso por La Carlota en algún momento que no nos precisa del año 1778, pero seguramente coincidiendo con algún día festivo destacado, nos dice que paseando de noche por sus calles había oído "Cánticos, danzas y el sonido de varios instrumentos" (HAMER Flores, Adolfo. La Carlota en los relatos de viajeros y escritores de los siglos XVIII y XIX. Madrid: Bubok Publishing, 2009, p. 45).

101. La información sobre esos bailes privados es muy escasa, pero no podemos descartar que, con la realización de algunos en las casas de los alcaldes pedáneos, como representantes que eran del gobierno civil de las colonias y de la administración de justicia, o, en su defecto, contando con la asistencia de estos, se pretendiese garantizar en teoría la inexistencia de excesos y actos contra la ley y las buenas costumbres.

102. PÉREZ FERnÁNDEZ, Francisco José. Cancionero popular de Aldeaquemada. Folclore de las Nuevas Poblaciones de Sierra Morena. Jaén: Diputación de Jaén, 2015, p. 53.

103. AHN, Inquisición, leg. 1866, pieza 3, testigo 141 (Juan Lanes y Duval, 1777). 
solo intervinieron españoles frente al caso de Arquillos donde bailaron todos sin distinción de nacionalidad. En lo que sí hubo una diferencia importante fue en los lugares donde tuvieron lugar pues, sin mediar autorización en ninguno de los dos casos, en Arquillos se realizó en la casa del colono José Figueroa mientras que en Santa Elena tuvo lugar, el 28 de diciembre por la tarde, en la plaza de la iglesia con acompañamiento de vihuela ${ }^{104}$.

Las jornadas festivas en el campo, herederas quizá de aquellos bailes impulsados en los departamentos a comienzos de 1768, también se mantuvieron como expresión del ocio popular. Tanto es así que contamos con un interesante testimonio, fechado en la tarde del 19 de abril de 1776, de la que hasta hace no muchos años tenía lugar en las proximidades del castillo de Tolosa, en la colonia de Navas de Tolosa. El viajero inglés Henry Swinburne nos dice que:

en una curva del camino, junto al dulce murmullo de un arroyo, nos encontramos con una docena de hombres bien ataviados y otras tantas damiselas inteligentes y hermosas bailando sobre una elevada plataforma de piedra. Las mujeres que no bailaban permanecían sentadas bajo árboles con ramas colgantes en un anfiteatro natural de rocas. Los hombres principales vinieron cortésmente hasta nosotros y nos invitaron a participar de su entretenimiento mientras que una chica muy hermosa nos regaló dulces y ciruelas azucaradas ${ }^{105}[\ldots$.... Permanecimos un rato con este alegre grupo, que bailó varias seguidillas y cantó varias canciones a petición nuestra ${ }^{106}$.

Comprobamos, pues, que la vida cotidiana de los colonos se adaptó con facilidad a los nuevos tiempos. Las medidas de Olavide encaminadas a modificar en las nuevas poblaciones el modelo de ocio habitual en otras zonas tuvieron un impacto muy limitado temporal y socialmente. Su proceder excesivamente paternalista se enfrentó a una sociedad que se resistió o aceptó como buenamente pudo unas transformaciones que nunca entendió y, por tanto, difícilmente podía compartir.

En otro orden de cosas, también en lo relacionado con los músicos residentes en las Nuevas Poblaciones, concretamente en las de Sierra Morena, notamos un descenso de su número a partir de la marcha de Olavide y, por tanto, de la interrupción de los bailes públicos. Los que quedaron se centrarían, sobre todo, en prestar sus servicios en esas fiestas privadas, en las que la calidad de la música ejecutada no sería tan importante como el poder disponer de alguna. Por ello,

104. AHN, Consejos, leg. 4057, exp. 11. Véase PÉREz Fernández, Francisco José. "Música y folclore en las Nuevas Poblaciones de Sierra Morena y Andalucía: estado de la cuestión y nuevas líneas historiográficas». Revista de Historiografía, 2018, 29, p. 322.

105. En el original se indica "sugar plums», un concepto que no implicaba necesariamente que siempre se tratase de ciruelas azucaradas, sino que también se aplicaba a una amplia variedad de frutas confitadas y nueces.

106. SwINBURNE, Henry. Travels through Spain in the years 1775 and 1776 in which several monuments of roman and moorish architecture. London: Printed for P. Elmsly, 1779, pp. 315-316. Traducción al español realizada por los autores. 
cuando visitaron La Carolina el conde de Artois (1782) y Carlos IV y su esposa (1796) fue necesario buscar músicos fuera de las colonias para amenizar sus estancias. El intendente Miguel de Ondeano solicitó, para la primera de ellas, varios músicos al deán de la Catedral de Jaén, en concreto trompas, oboes, violines y un célebre bajonista con un repertorio de sonatas y oberturas, muy del gusto de la época, para que le proporcionaran "[...] honesta diversión de un rato de música". En el caso de la estancia de los monarcas, también solicitaría a la misma institución cuatro violines, dos trompas, dos oboes, dos flautas, un contrabajo y un violón; es decir, un total de doce músicos ${ }^{107}$. Así pues, de una abundante presencia de músicos en los primeros años de la colonización se pasó, en poco más de una década, a no disponer en las Nuevas Poblaciones ni de un número mínimo de ellos para atender eventos sin grandes boatos como los que acabamos de mencionar.

\section{CONCLUSIONES}

"Reconvino al superintendente don Pablo de Olavide, actual asistente de Sevilla, diciéndole no se debían permitir semejantes diversiones, siquiera porque hay infierno, y dicho Olavide le respondió: déjese de eso padre, que no hay más infierno que el que se pasa en este mundo» ${ }^{108}$. Este testimonio, seleccionado a modo de ejemplo, constituye una prueba muy elocuente del rechazo que generaban las iniciativas en materia de ocio que el limeño aplicaba en las Nuevas Poblaciones durante su etapa de gobierno. Su distanciamiento de las normas y convenciones sociales facilitó que muchos las vieran como deshonestas y, por tanto, clamaran por su supresión.

En las nuevas colonias este aspiraba a implantar un nuevo modelo de religiosidad y de ocio, siempre subordinado al trabajo. El desmonte de terrenos para lograr espacios cultivables, las labores agrarias o la construcción de casas no debían interrumpirse durante días completos por más que en el calendario se correspondiesen con festividades. Aun así, parte de esas jornadas siempre pudieron ser empleadas por los colonos para asistir a las funciones religiosas y para divertirse. Un tiempo de ocio que, desde fechas muy tempranas, se procuró desde el poder que se orientase hacia los bailes públicos. Existían otras actividades, como juegos de bolear o incluso los toros, pero fueron los bailes los que contaron con más apoyo e impulso por parte de Olavide. Sin duda, a través de ellos pretendió normalizar y difundir nuevas formas de vestir y de sociabilizar, facilitando el éxito de las nuevas colonias con la formación de nuevas familias y la interrelación entre individuos con orígenes y lenguas muy diferentes.

107. PÉREZ FERNÁNDEZ, Francisco José. «Algunas notas sobre la música culta en las Nuevas Poblaciones de Sierra Morena". Boletín del Centro de Estudios Neopoblacionales, 2016, 9-10, pp. 38-39.

108. AHN, Inquisición, leg. 1866, pieza 1, testigo 44 (José Antonio de Losada, 1777). Esta conversación había tenido lugar entre Carlos de Silva y Pablo de Olavide. 
Aunque también estuvieron presentes en los departamentos de las distintas colonias, sería el baile público celebrado en La Carolina, capital de las Nuevas Poblaciones de Sierra Morena, el que mejor mostró la impronta del superintendente. Su firme voluntad de que la asistencia fuera multitudinaria, por no establecer limitaciones a las formas de bailar (aunque algunas con origen extranjero resultasen indecorosas para los españoles, menos habituados al contacto físico) y por impedir que las mujeres participaran con cabezas, cuellos y hombros cubiertos, nos deja entrever una clara voluntad no solo por fomentar esa mencionada integración de gentes con orígenes muy heterogéneos, sino también por incentivar la aparición de nuevas parejas que asegurasen con su descendencia el éxito del proyecto. La respuesta del clero, aunque tímida por las enormes competencias de Olavide en materia eclesiástica, no se hizo esperar rechazando estos bailes; especialmente entre los religiosos alemanes, que podían censurarlos con más facilidad en sus sermones dada la dificultad de la Administración para comprender el alemán. No obstante, su capacidad real para oponerse fue siempre muy limitada mientras el superintendente estuvo al frente de las nuevas colonias.

Por otro lado, parece que también estuvieron presentes en La Carolina otras actividades de ocio vinculadas a los sectores más elitistas (bailes de máscaras y teatro), pero todo apunta a que estuvieron restringidas al espacio estrictamente doméstico del superintendente. Vinculadas habitualmente a las clases altas, Olavide nunca tuvo, por tanto, intención de difundirlas entre una sociedad eminentemente agraria, muy diferente a la existente en la gran urbe sevillana, donde sí trató de impulsarlas con firmeza, aunque sin demasiado éxito.

Ahora bien, la escasa aceptación social del modelo de ocio que aquí analizamos quedó al descubierto en 1776. Con la real orden para que acudiera a la corte y su posterior encarcelamiento por la Inquisición, gran parte de las medidas que reformaban la religiosidad y las actividades en el tiempo libre de los colonos se diluyeron con rapidez. Los bailes públicos dejaron de celebrarse ese mismo año, impulsándose un mayor control de las buenas costumbres. Así pues, se ponía fin a una interesante experiencia ilustrada y las actividades de ocio existentes en las nuevas colonias pasaron a ser similares a las de cualquier lugar del entorno.

\section{BiBLIOGRAFÍA}

Aguilar Piñal, Francisco. Sevilla y el teatro en el siglo XVIII. Oviedo: Universidad de Oviedo, 1974.

ALCÁZAR Molina, Cayetano. Las colonias alemanas de Sierra Morena. Madrid: Universidad de Murcia, 1930.

Amigo VÁzQuez, Lourdes. «El escenario taurino. Plazas mayores y plazas de toros (siglos XVI-XVIII)». Andalucía en la Historia, 2015, 48, pp. 8-13.

ANDIOC, René. El teatro en el siglo XVIII. Madrid: Taurus, 1982.

ANDIOC, René. Teatro y sociedad en el Madrid del siglo XVIII. Madrid: Castalia, 1988. 
ARIAS De SAAVEDRa AlíAs, Inmaculada (coord.). Vida cotidiana en la España de la Ilustración. Granada: Universidad de Granada, 2012.

Barrera, Trinidad y Bolaños, Piedad. "La labor teatral en Sevilla del peruano Pablo de Olavide». En Torres Ramírez, Bibiano y Hernández Palomo, José (eds.). Andalucía y América en el siglo XVIII. Actas de las IV Jornadas de Andalucía y América. Sevilla: CSIC, 1985, pp. 23-56.

Bejarano Pellicer, Clara. «Sociabilidad, música y danza en el siglo XVIII». En Fernández Cortizo, Camilo; Migués Rodríguez, Víctor Manuel y Presedo Garazo, Antonio (eds.). $E l$ mundo urbano en el siglo de la Ilustración. IX Reunión Científica de Historia Moderna. Santiago de Compostela: Xunta de Galicia, 2009, vol. 1, pp. 293-305.

Bolaños Donoso, Piedad. "Un coliseo de comedias para la ciudad de Écija (1772)». En Álvarez BARRIENTOS, Joaquín y CheCa BeltrÁn, José (coords.). El siglo que llaman ilustrado. Homenaje a Francisco Aguilar Piñal. Madrid: CSIC, 1996, pp. 113-124.

BONET CORREA, Antonio. Morfología y ciudad: urbanismo y arquitectura durante el Antiguo Régimen de España. Barcelona: Editorial Gustavo Gili, 1978.

Capel Margarito, Manuel. La Carolina, capital de las nuevas poblaciones. (Un ensayo de reforma socio-económica de España en el siglo XVIII). Jaén: CSIC e Instituto de Estudios Giennenses, 1970.

CARO LÓPEZ, Ceferino. "Censura gubernativa, Iglesia e Inquisición en el siglo XVIII». Hispania Sacra, 2004, 56, pp. 479-511.

Casanova, Giacomo. Memorias de España. Barcelona: Áltera, 2001.

CÉSPEDES Y MONROY, Atanasio. Lecturas útiles y entretenidas. Lectura veinte y nueve. La familia feliz. Parte Primera. Madrid: En la Oficina de Dávila, 1817.

CORONAS VIDA, Luis Javier. "Colonos catalanes en las Nuevas Poblaciones de Sierra Morena". En Actes Primer Congrés d'Història Moderna de Catalunya. Barcelona: Universitat de Barcelona, 1984, I, pp. 39-44.

Cossío, José María de. Los toros. Tratado técnico e histórico. Madrid: Espasa-Calpe, 1995, II.

CuAdro García, Ana Cristina. La época de la Ilustración en Córdoba. Córdoba: Universidad de Córdoba, 2007.

Defourneaux, Marcelin. Pablo de Olavide, el afrancesado. México: Editorial Renacimiento, 1965. Traducción al español del original francés: Pablo de Olavide ou l'Afrancesado. Paris: Presses Universitaires de France, 1959.

Dufour, Gérard. Cartas de Mariano a Antonio. El programa ilustrado de El Evangelio en triunfo. Provence: Université de Provence, 1988.

Fernández de la Cigoña, Francisco José y Cantero NúÑez, Estanislao. Antonio de Capmany (1742-1813). Pensamiento, obra histórica, política y jurídica. Madrid: Fundación Francisco Elías de Tejada y Erasmo Percopo, 1993.

GÓMEZ URDÁÑ̃EZ, José Luis. «Con la venia de Carlos III. El castigo ejemplar de Olavide, consecuencia de la venganza de Grimaldi contra el conde de Aranda». Vegueta. Anuario de la Facultad de Geografia e Historia, 2015, 15, pp. 373-400.

HAMER Flores, Adolfo. «Las Nuevas Poblaciones de Andalucía a finales del siglo XVIII según el Diccionario Geográfico-Histórico de Tomás López». Ámbitos. Revista de Estudios de Ciencias Sociales y Humanidades, 2005, 14, pp. 89-102.

HAMER FloRES, Adolfo. La Carlota en los relatos de viajeros y escritores de los siglos XVIII y XIX. Madrid: Bubok Publishing, 2009.

HAMER Flores, Adolfo (ed.). Legislación Histórica Neopoblacional. Disposiciones normativas emanadas del poder central en las Nuevas Poblaciones de Sierra Morena y Andalucía (1767-1835). Madrid: Bubok Publishing, 2018. 
REFORMAR LAS COSTUMBRES. PABLO DE OLAVIDE Y SU MODELO DE OCIO PARA LAS NUEVAS...

Jovellanos, Gaspar Melchor de. Espectáculos y diversiones públicas. Informe sobre la Ley Agraria. Madrid: Cátedra, 1998.

LERA GarCía, Rafael de. "Conflictividad social en las Nuevas Poblaciones de Sierra Morena 1767-70». En AvilÉs, Miguel y SENA, Guillermo (eds.). Carlos III y las «Nuevas Poblaciones». Córdoba: Universidad de Córdoba, 1988, pp. 41-55.

MARín López, Javier. «Cultura musical y Nuevas Poblaciones». En TARIFA FernándeZ, Adela; Fílter Rodríguez, José Antonio y Ruiz Olivares, Amparo (coords.). Congreso Internacional Nuevas Poblaciones de Sierra Morena y Andalucía y otras colonizaciones agrarias en la Europa de la Ilustración. Jaén: Diputación de Jaén, 2018, pp. 1523-1547.

Moreno Mengíbar, Andrés. "Los orígenes de la ópera en Sevilla. La actuación de Olavide (1767-1779)». Archivo Hispalense, 1989, 221, pp. 17-32.

NúÑEZ Roldán, Francisco (coord.). Ocio y vida cotidiana en el mundo hispánico en la Edad Moderna. Sevilla: Universidad de Sevilla, 2007.

Olavide, Pablo de. Plan de estudios para la Universidad de Sevilla. Madrid: Ediciones de Cultura Popular, 1969.

Palacio ATARD, Vicente. Los españoles de la Ilustración. Madrid: Ediciones Guadarrama, 1964.

Perdices De Blas, Luis. Pablo de Olavide (1725-1803), el ilustrado. Madrid: Universidad Complutense, 1992.

PERDICES DE BLAS, Luis. «Pablo de Olavide (1725-1803) a través de sus estudios». Cuadernos Dieciochistas, 2003, 4, pp. 13-30.

Pérez Fernández, Francisco José. Cancionero popular de Aldeaquemada. Folclore de las Nuevas Poblaciones de Sierra Morena. Jaén: Diputación de Jaén, 2015.

PÉREZ FERnÁNDEZ, Francisco José. Aldeaquemada. Riqueza territorial, industrial y comercial de 1813. Aldeaquemada: Centro de Estudios Neopoblacionales, 2015.

PÉREZ FERNÁNDEZ, Francisco José. "Algunas notas sobre la música culta en las Nuevas Poblaciones de Sierra Morena». Boletín del Centro de Estudios Neopoblacionales, 2016, 9-10, pp. 35-52.

Pérez Fernández, Francisco José. "Música y folclore en las Nuevas Poblaciones de Sierra Morena y Andalucía: estado de la cuestión y nuevas líneas historiográficas». Revista de Historiografia, 2018, 29, pp. 313-328.

Pérez Fernández, Francisco José. Colonos y propietarios de las Nuevas Poblaciones de Sierra Morena durante la Edad Moderna (Tesis doctoral inédita). Universidad de Jaén, 2019.

RICo OsÉs, Clara. «La contradanza en España en el siglo XVIII: Ferriol y Boxeraus, Minguet e Yrol y los bailes públicos». Anuario Musical, 2009, 64, pp. 191-214.

Rodríguez López-Brea, Carlos María. Dos Borbones, cardenales primados en Toledo. Cuenca: Universidad de Castilla-La Mancha, 2001.

SÁnchez Martínez, Carlos. Datos para la bistoria antigua carolinense. La Carolina: Seminario de Estudios Carolinenses, 1982.

SÁnChez-BAtalla Martínez, Carlos. La Carolina en el entorno de sus colonias gemelas y antiguas Poblaciones de Sierra Morena. Prebistoria a 1835. Jaén: Caja Rural de Jaén, 2000, II.

SWINBURNE, Henry. Travels through Spain in the years 1775 and 1776 in which several monuments of roman and moorish architecture. London: Printed for P. Elmsly, 1779.

TORRIOne, Margarita (dir.). España festejante: el siglo XVIII. Málaga: Diputación de Málaga, 2000. 
